Research Report No. 29/2010

\title{
The Acceptable Limits of State Interference in Private Property Rights During Periods of Economic Crisis
}

Ian Payne

Follow this and additional works at: http://digitalcommons.osgoode.yorku.ca/clpe

\section{Recommended Citation}

Payne, Ian, "The Acceptable Limits of State Interference in Private Property Rights During Periods of Economic Crisis" (2010). Comparative Research in Law \& Political Economy. Research Paper No. 29/2010.

http://digitalcommons.osgoode.yorku.ca/clpe/96 


\section{OSGOODE}

OSGOODE HALL LAW SCHOOL Y O R K N I V ER S I T Y

\section{OSGOODE HALL LAW SCHOOL Comparative Research in Law \& Political Economy}

RESEARCH PAPER SERIES

Research Paper No. 29/2010

\section{Editors:}

Peer Zumbansen (Osgoode Hall Law School, Toronto, Director, Comparative Research in Law and Political Economy)

John W. Cioffi (University of California at Riverside)

Lisa Philipps (Osgoode Hall Law School, Associate Dean Research)

Nassim Nasser (Osgoode Hall Law School, Toronto, Production Editor)

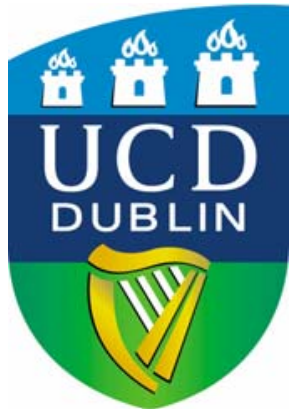

\section{UCD WORKING PAPERS IN}

LAW, CRIMIN OLOGY \&

SOCIO-LEGAL STUDIES

Research Paper No. 32/2010

Editors:

Blanaid Clarke, Associate Professor in Corporate Law and Director of Research, UCD School of Law

Colin Scott, Professor of EU Regulation and Governance and Director, UCD Centre for Regulation and Governance, University College Dublin

\section{The Acceptable Limits of State Interference in Private Property Rights during Periods of Economic Crisis}

lan Payne 
CLPE Research Paper 29/2010

Vol. 06 No. 07 (2010)

UCD Research Paper 32/2010

\title{
The Acceptable Limits of State Interference in Private Property Rights during Periods of Economic Crisis
}

\begin{abstract}
The power of the state to compulsorily acquire the privately held real property of citizens is recognised in numerous developed democracies. However, the exercise of this power remains extremely controversial. In most jurisdictions the state's power to compulsorily acquire private property is limited to instances of necessary public good. In many instances, such as hospitals or railways, a necessary public good is clearly identifiable. However, successive United States Supreme Court judgments have expanded the definition of public good to include redevelopment which is primarily to the benefit of another private party. The Supreme Court judgment in Kelo $v$ City of New London sparked a political outcry which led to severe limitations being placed on the power of state authorities to compulsorily acquire property for private redevelopment. Given the jurisprudence of the Irish Supreme Court in cases such as Clinton v An Bord Pleanála and others it is likely that the attitude of the Irish courts would be similar to that of their American counterparts in Kelo. Proponents of the Coase Theorem argue that the state should take a secondary role in such property disputes, leaving resolution to be achieved through private bargaining between the parties. However, this approach is predicated on an illusion of minimal transaction cost. The effectiveness of such an approach also declines as the distance between the parties to the transaction increases. Furthermore, property rights cannot be understood in purely economic terms. The role of law must be to delineate property rights in a manner which takes account of, and balances, private economic and other arguments such as community cohesion, economic development and social justice concerns.
\end{abstract}

Keywords: Eminent Domain, Compulsory Acquisition, Public Good, Kelo, Coase Theorem

JEL Classification: K11

\author{
Ian Payne \\ University College Dublin \\ Email: ian.payne@ucdconnect.ie
}




\title{
The Acceptable Limits of State Interference in Private Property Rights during Periods of Economic Crisis
}

\author{
Ian Payne*
}

The limited right of the state to compulsorily acquire the privately held real property of citizens is recognised in numerous developed market democracies. ${ }^{1}$ However, the exercise of this power remains extremely controversial. In most jurisdictions the state's power to acquire property under this domain is limited to instances of necessary public good. Article 8.2 of the European Convention on Human Rights provides that instances justifying such interference by the state include on the basis of national security, public safety and the economic well-being of the country.

A central problem in theorising the acceptable limits of such intervention remains the competing concepts of public good, which inevitably change over time, and frequently depend on circumstance. It will be demonstrated that the concept of "public good" has been expanded over time to potentially include the compulsory conveyance of property from one private party to another, where the state considers it economically or socially expedient to do so. This essay will consider the role which law must play in regulating competing notions of public good in order to provide a regime which balances a requirement of justice with the goal of stable market expectations within an economy. In doing so it will first be necessary to consider the role of compulsory acquisition in an Irish and, briefly, in an American context.

\section{Private Property Rights in IRELAND}

Bunreacht na hÉireann ${ }^{2}$ provides the basis for the recognition of private property in the Irish legal order. Reference to private property rights appear in two distinct articles of the Constitution. Article 43.1 provides that man has a right to the private ownership of external goods. It further provides that the State shall pass no law attempting to abolish this right of private ownership. However, this right is qualified by Article 43.2 which provides that the rights outlined in Article 43.1 should be regulated by the principles of social justice and, to that end, the State may delimit the exercise of such rights with a view to reconciling their exercise with the exigencies of the common good. Furthermore, Article 43 must be read in conjunction with Article 40.3 which - under the heading of

\footnotetext{
*Ian Payne, University College Dublin, Email: ian.payne@ucdconnect.ie

${ }^{1}$ For example, in England - Planning and Compulsory Purchase Act, 2004; In France - Article 7 Declaration of the Rights of Man and of the Citizen, 1789; In Germany - Article 14 Basic Law for the Federal Republic of Germany.

${ }^{2}$ The Irish Constitution
} 
Personal Rights - provides that the State shall, "in particular, by its laws protect as best it may from unjust attack and, in the case of injustice done, vindicate the... property rights of every citizen".

It thus appears that private property rights, being mentioned in two distinct articles of the Constitution, enjoy an extremely privileged place in Irish law. However, it is not the case Irish law treats property rights as sacrosanct. J.M. Kelly's, The Irish Constitution, notes that "legislative restrictions on property rights are usually upheld by the courts, with only a small minority of cases establishing an infringement of the constitutional guarantee of private property". ${ }^{3}$ Following larnród Éireann $v$ Ireland ${ }^{4}$ it is now the position of the Irish High Court that the provisions of the Constitution protecting private property apply equally to corporate bodies as they do to human persons. The issues addressed by Keane J. in the High Court have not yet been considered by the Supreme Court. The extension of such constitutional protection to corporate bodies has been criticised by the Irish Constitutional Review Group. ${ }^{5}$

\section{The United States Following Kelo}

The right of the state to compulsorily acquire property in the USA was limited by the Fifth Amendment, which came into effect in 1791 as part of the United States Bill of Rights. The text of the Fifth Amendment includes, inter alia, the following provision.

No person... shall be... deprived of life, liberty, or property, without due process of law; nor shall private property be taken for public use, without just compensation.

The tying of private property rights, in the same provision, to the rights of life and liberty demonstrates the sensitive nature of this bundle of rights. Any prospect of undue interference with these rights has the potential to spark highly charged political debate.

The US Supreme Court has, for a considerable period of time, upheld the right of the legislature to compulsorily acquire property under the Fifth Amendment, even in favour of private parties, where the result is the delivery of a public benefit. ${ }^{6}$ However, the decision of the Supreme Court to uphold the compulsory acquisition of private dwellings by the City of New London in Kelo $v$ City of New London ${ }^{7}$ sparked a political backlash not experienced before in respect of this classic police power of the state.

\footnotetext{
${ }^{3}$ GW Hogan and GF Whyte, JM Kelly: The Irish Constitution (4 ${ }^{\text {th }}$ edn Tottel, Dublin 2003) 1970

${ }^{4}$ [1996] 3 IR 321

${ }^{5}$ Report of the Constitutional Review Group (Pn 2632, 1996) 343

${ }^{6}$ Hawaii Housing Authority v Midkiff 467 U.S. 229 (1984)

${ }^{7} 545$ U.S. 469 (2005)
} 
The dispute in Kelo arose from the decision of the City of New London to implement a development plan in order to regenerate an area of the city which was suffering from deprivation and mass unemployment. This required the compulsory acquisition of large tracts of land in that area. The city's population had declined almost thirty percent since 1960 , and its unemployment level was twice the state average. ${ }^{8}$ The plan envisaged the creation of new restaurants, stores and a museum. The anchor of the entire scheme was a proposal to develop a $\$ 300$ million Pfizer research facility. ${ }^{9}$ The case hinged on whether it was constitutional for the City of New London to compulsorily acquire the property of Susette Kelo, where the public benefit of such a seizure would be indirect. In this instance it appeared that the direct, and majority, benefit would be to Pfizer. The company would have a site secured on its behalf and would benefit from significant tax breaks following the establishment of the research centre.

Delivering the judgment of the court, Justice Stevens held that it would not be constitutional for the city to take property under a mere pretext of a public purpose. However, the court determined that the taking in question was exercised in pursuance of a "carefully considered" development plan which was not adopted "to benefit a particular class of identifiable individuals". Justice Stevens concluded that the Supreme Court of the United States rejects the notion that in order for a taking to have public benefit, the property in question must be literally put to any particular use for the general public.

This Supreme Court judgment sparked a considerable outcry from conservative supporters of private property rights. In her dissenting judgment, Justice Day O'Connor stated,

Any property may now be taken for the benefit of another private party, but the fallout from this decision will not be random. The beneficiaries are likely to be those citizens with disproportionate influence and power...the government now has license to transfer property from those with fewer resources to those with more.

Justice Day O'Connor's dissent continues to resonate with many Americans. Echoing her judgment, a Wall Street Journal editorial in 2009 opined that the decision of the Court in Kelo handed a 'carte blanche' to local government in order to seize private property for economic development. ${ }^{10}$ The outcry which followed Kelo resulted in hasty legislative change in many states. The conservative Institute for Justice claims that $\mathbf{4 3}$ of the states of America have engaged either in substantive eminent domain reform or have increased eminent domain protections in the wake of Kelo. ${ }^{11}$

\footnotetext{
${ }^{8}$ E Rutkow, 'Kelo v City of New London' (2006) 30 Harv.Envtl.L.Rev. 261-279, 261

${ }^{9}$ Editorial, 'The Limits of Property Rights', New York Times (New York 24 June 2005)

${ }^{10}$ Editorial, 'Pfizer and Kelo's Ghost Town' Wall Street Journal (New York 11 November 2009)

${ }^{11}$ Castle Coalition, 'Legislative Center'
} 


\section{KELO IN AN IRISH CONTEXT}

Although there has been no judgment by an Irish court in a case with facts identical to those in Kelo, the Irish Supreme Court has considered compulsory acquisition in the context of schemes which include a private dimension. In Clinton v An Bord Pleanála and others $^{12}$ Geoghegan J., in a unanimous judgment of the Supreme Court, held that a compulsory acquisition by Dublin City Council, pursuant to a regeneration plan for O'Connell Street, was constitutional notwithstanding the fact that the specific purpose to which the site in question would be put was unclear, and notwithstanding the likelihood that the regeneration would be achieved through a public-private partnership.

Whereas, a case with the specific facts of Kelo has not yet arisen in Ireland, the underlying arguments which it was necessary for the US Supreme Court to engage with in that case are prominent in Irish political discourse. This is particularly so at this moment in time, as the Government faces a public demand to do more in order to stimulate employment at a time of economic crisis.

In February 2010 public controversy arose in Ireland following a proposal by Ryanair to create 500 jobs in a facility at Dublin Airport. This offer was conditional on the current tenants of the facility - Ryanair's major competitor Aer Lingus - being forced to vacate the property. At the time, the Government parties came under considerable pressure to yield to Ryanair's request, on the basis of economic expediency. ${ }^{13}$ However, the Government refused to intervene in this manner. In March, Ryanair announced that the 500 jobs will be created at facilities outside of Ireland.$^{14}$ It is clear that if the Government had sought the compulsory acquisition of the facility at Dublin Airport, Aer Lingus would have enjoyed the right to challenge that acquisition through the courts. larnród Éireann is authority that corporations do enjoy property rights akin to human persons under Bunreacht na hÉireann. However, it is not certain what the outcome of such a challenge might be. It is stated above that, historically, the Irish Supreme Court has been largely deferential to the legislature in instances of compulsory acquisition.

Rachael Walsh of Trinity College Dublin maintains that since Clinton the Irish courts are on a path towards approving compulsory acquisitions whose primary consequence is the conferring of benefit on private developers. Walsh continues, citing with approval Justice

\footnotetext{
<http://www.castlecoalition.org/index.php?option=com_content\&task=view\&id=34\&/temid=119> Accessed 3 May 2010

12 [2007] IESC 19

${ }^{13}$ F O'Dowd, 'Hanger 6 at Dublin Airport: Discussion' (Joint Committee on Transport, 24 February 2010)

${ }^{14}$ Ryanair, 'Irish Government Inaction Cost 500 Engineering Jobs Which will now be lost to Europe' <http://www.ryanair.com/en/news/irish-govt-inaction-costs-500-engineering-jobs> Accessed 4 May 2010
} 
Day O'Connor in Kelo, that such a development may undermine the consonance of the Irish property rights regime with social justice. ${ }^{15}$

\section{The DANGER OF AN UnCHECKED StATE}

Walsh may be correct in her concerns regarding compulsory acquisition for private redevelopment in distinguishable instances. In Kelo, despite the compulsory acquisition of property in an economically deprived area proceeding, the regeneration plan stalled. The Pfizer investment never materialised and subsequently the company pulled out of New London altogether costing 1,400 jobs. ${ }^{16}$ Arguably the episode resulted in the destruction of a cohesive community while delivering no economic benefit. However, the underlying substance of the assumption that compulsory acquisition for private redevelopment is inherently incompatible with social justice is inadequate and cannot be applied as a general rule.

The extent to which the state may legitimately interfere in regulating competing property rights between individuals has long been a matter of debate between scholars and in the courts. In Lochner $v$ New York ${ }^{17}$ the US Supreme Court considered the extent to which the New York State Legislature could be permitted to interfere in the contract between a baker and his employee in respect of working conditions. In the instant case the majority of the court held that a law which sought to limit the number of hours an employee could work in a bakery per day was an "unreasonable, unnecessary and arbitrary interference with the right and liberty of the individual to contract". However, in his frequently cited dissenting judgment, Justice Holmes held that a judge's agreement or disagreement with a particular economic theory should not interfere with the right of the majority to embody their opinions in law. Justice Holmes maintained that "the word liberty in the Fourteenth Amendment is perverted when it is held to prevent the natural outcome of dominant opinion".

\section{THE COASE THEOREM}

Scholars of Law and Economics have often sought to minimise the role of the state, or indeed the law, in regulating the economic interactions which take place between private parties. In 'The Problem of Social Cost', Nobel Laureate Ronald Coase introduced the notion of private bargaining, based on clearly established property rights, as being potentially more efficient than state intervention. Coase rejected the traditional approach to legal rules whereby the question arising from the example of one party inflicting harm on another is how to restrain the harm inflicting party. Instead, Coase

$15 \mathrm{R}$ Walsh, 'Compulsory Acquisition for Private Redevelopment - Lessons from the U.S.' $<$ http://humanrights.ie/2010/03/06/guest-contribution-walsh-on-compulsory-acquisition-for-privatedevelopment/> Accessed 17 March 2010

${ }^{16}$ P McGeehan, 'Pfizer to Leave City That Won Land-Use Suit' New York Times (New York 13 November 2009)

17198 U.S. 45 (1905) 
maintains that the problem is reciprocal. Restraining the tortfeasor who is infringing the rights of another party may in fact cause greater economic or social harm than restricting the right of that other party to procure a remedy.

Coase applied his argument, with considerable effect, to the classic case of Sturges $v$ Bridgman. ${ }^{18}$ The case concerned an allegation of nuisance which arose when a doctor extended his premises for the purposes of developing his private practice. The extension so happened to border on the kitchen of his neighbour, a confectioner. The doctor sought, and obtained, an injunction on the basis of the nuisance arising from the carrying out of the confectioner's business, which disrupted his medical practice. This was despite the confectioner's activity predating the construction of the doctor's consultation room. In 'The Problem of Social Cost', Coase argued that a more efficient means of solving this dispute would have been for the parties to bargain privately in order to achieve the most economically efficient outcome.

"If the doctor's income would have fallen more through continuance of this machinery than it added to the income of the confectioner, there would clearly be room for a bargain whereby the doctor paid the confectioner to stop using the machinery" ${ }^{19}$

Underlying the Coase Theorem, as it later became known, is an aspiration to minimise transaction costs between parties in order that they may bargain privately. Ideally transaction costs should reach zero. This approach continues to be a focus for many scholars today in respect of the issues under discussion in this essay. The issue of compensation is often central to finding a resolution acceptable to the different parties involved in a compulsory acquisition dispute. Drawing on the example of Kelo and other examples from the United Kingdom, Stephen Crow concluded, in 'Compulsory Purchase for Economic Development: An International Perspective', that if an acquisition were to take place on the basis of "truly voluntary negotiations" between equal parties, it is more likely that the agreed price would include some element of the profits anticipated by the developer of the site to be acquired..$^{20}$ It is argued that such a resolution would be to the benefit and the satisfaction of the party who is subject to a compulsory acquisition order. Those who focus predominantly on transaction costs argue that greater equality in bargaining could be achieved through policies which seek to minimise such externalities.

These sentiments are partly echoed in Robert Ellickson's landmark text, Order Without Law. In 1981, Ellickson travelled to Shasta County, California, in order to examine whether the Coase Theorem - that portrays people as bargaining to mutual advantage from whatever starting points the legal system has bestowed on them - applies to the

\footnotetext{
${ }^{18}$ [1879] LR 11 Ch D 852

${ }^{19}$ R Coase, 'The Problem of Social Cost' (1960) 3 Journal of Law and Economics 1-44, 9

${ }^{20}$ S Crow, 'Compulsory Purchase for Economic Development: An International Perspective' (2007) J.P.L 1102-1115, 1114
} 
reality of border and herding disputes in a rural context. ${ }^{21}$ Ellickson discovered that some spheres of life do lie entirely beyond the shadow of the law. In respect of many disputes, parties privately bargained a mutually acceptable solution irrespective of their applicable legal rights. However, Ellickson also observed that as the magnitude of what is at stake, or the distance between the parties, increased, disputants became increasingly likely to turn to legal rules in order to resolve a dispute. Furthermore, despite appearing largely in favour of private bargaining, Ellickson concedes in the concluding chapter that local bargaining provides no basis for expecting that norms will serve corrective ends, such as distributive justice, which policymakers may consider important or even necessary. ${ }^{22}$ It is apparent that private bargaining does have natural limitations when applied to concrete situations. Therefore, the role of the state, and of law, will often be imperative when compulsory acquisition is considered necessary.

\section{Defining the Public GoOd}

An attempt to define the "public good" is important in the context of compulsory acquisition as most jurisdictions limit such acquisitions to instances of necessary public benefit. However, it is clear that in a heterogeneous society, concepts of public good are constantly competing. In Lochner $v$ New York, despite coming to entirely different conclusions, both the majority of the court and Justice Holmes, dissenting, sought to establish legal principles which were to the benefit of the public.

The Coase Theorem, which seeks to minimise transaction costs in order to encourage private bargaining has natural limitations, as demonstrated by the short review of Ellickson's findings. It may provide a simple solution to many disputes; an effective means of ensuring the most economically efficient outcome. However, an efficient outcome is not always assured, and equally, the approach takes no account of the corrective aspirations which are often identified by the legislature. Moreover, the effectiveness of the theorem is based on the abstract notion of transaction costs being extremely low. This limitation was not lost on Coase who himself emphasised that the problem of welfare economics must "ultimately dissolve into a study of aesthetics and morals". ${ }^{23}$ As Charles Tiebout has highlighted, issues cannot be decided entirely on the basis of cost unless the social welfare function is also known. ${ }^{24}$

Furthermore, an unqualified application of the argument espoused by the majority in Lochner $v$ New York, which is reflected in the Coase Theorem, namely that parties should bargain privately without the interference of the state, requires several assumptions regarding property rights which do not necessarily hold true. As stated, parties can only

${ }^{21}$ RC Ellickson, Order without Law: how neighbors settle disputes (Harvard University Press, London 1991) vii

22 Ibid., 283-284

${ }^{23}$ Coase, 'The Problem of Social Cost', 43

${ }^{24}$ CM Tiebout, 'A Pure Theory of Local Expenditures' (1956) 64 Journal of Political Economy 416-424, 423 
bargain privately effectively where there exists a relative equality of bargaining power between the parties. Moreover, each party must be able to, and be prepared to, place an economic value on their particular rights. If this were always the case, there would never be need for the state to interfere in order to regulate competing interests through compulsory acquisition for private redevelopment. However, Janice Nadler and Shari Diamond have identified that in many instances of compulsory acquisition, the party resisting such acquisition is not simply a "hold out" seeking a more favourable economic bargain but rather is a "hold in" - with a strong subjective attachment to their property. Such parties may be unwilling to voluntarily sell their property at any price. ${ }^{25}$ This is particularly so where there is no clearly defined public benefit arising from the transaction, as is often the case where a property is acquired for private redevelopment under a broad scheme of urban renewal.

For the Coase Theorem to be truly effective, in addition to requiring very low transaction costs, it requires clearly established property rights. However, such inalienable property rights do not exist. There are a plethora of regulatory interventions by the state which define what one can and cannot do in respect of property over which one holds title. Some scholars, such as Garrett Hardin, have suggested that an increase in the scope of private property rights may overcome many of the social difficulties faced by society. This is a position reflective of the majority judgment in Lochner. In 'The Tragedy of the Commons', Hardin refers to the example of a herdsman who, as a rational actor, seeks to maximise his gain, by increasing the size of his herd which grazes on the commons. If each herdsman acts in this self interested fashion, which most inevitably will, without an overarching governance structure, the eventual result will be the destruction of the entire resource; in Hardin's example, a common pasture. ${ }^{26}$ Many scholars have argued, using Hardin's thesis, that this tragedy, may be overcome by increased privatisation of the commons.

However, deference to a rule of law which values privatisation over all other considerations is likely to create as many problems as would the 'Tragedy of the Commons' as outlined by Hardin. Friedrich von Hayek may be correct in some circumstances that decentralisation to local experts is preferable to central state intervention. ${ }^{27}$ However, this cannot satisfy the quandary, as outlined by Nadler and Diamond, that in many instances a party who is subject to a compulsory purchase order may value their property in subjective, even irrational, terms; and that in adopting such an entrenched position, the wider society may suffer. This is likely to become particularly pronounced at a time of economic crisis. The same concern can be applied equally in respect of a law which permits the legislature to seize property on behalf of another private party without requiring any demonstration of a necessary public benefit. This was

\footnotetext{
$25 \mathrm{~J}$ Nadler and SS Diamond, 'Eminent Domain and the Psychology of Property Rights: Proposed Use, Subjective Attachment, and Take Identity' Northwestern Public Law Research Paper No. 08-24. Available at http://ssrn.com/abstract=1162789, 10

${ }^{26}$ G Hardin, 'The Tragedy of the Commons' (1968) 162 Science 1243-1248

${ }^{27}$ FA Hayek, 'The Use of Knowledge in Society' (1945) 35 The American Economic Review 519-530, 524
} 
the concern of Justice Day-O'Connor in Kelo. However, in Kelo the learned judge's concern was misplaced.

\section{LAW AS AN UMPIRE}

From the above it is clear that neither the extreme of fully privatised property rights, nor of arbitrary state intervention can provide an adequate means of governance which recognises the private rights of individuals but also takes cognisance of economic efficiency and a desire for corrective justice. It is apparent that law can play a role as an umpire in order to balance these competing rights. The law must delineate property rights in a manner which takes account of private economic and other arguments such as community cohesion, economic development, as well as social justice and morality concerns.

This is an argument which is not lost on the judiciary. It is clear from the jurisprudence of the Irish Supreme Court that the court takes seriously its role of acting as an umpire between competing rights and notions of justice. In Tuohy $v$ Courtney $^{28}$ the Supreme Court, echoing Justice Holmes in Lochner, held that the function of the Court is not to substitute its view of the correct or desirable balance for that of the Oireachtas (the legislature) but rather,

"To determine from an objective stance whether the balance contained in the impugned legislation is so contrary to reason and fairness as to constitute an unjust attack on some individual's constitutional rights"

The doctrine of proportionality, outlined in Tuohy, is one of the most important examples of the law acting as an umpire in order to ensure that a balanced outcome is arrived at in respect of disputes regarding real property.

Critiquing the 'Tragedy of the Commons', Elinor Ostrom - in Governing the Commons: The Evolution of Institutions for Collective Action - provides the basis for a different approach to regulatory governance, which rejects the rigid dichotomy between the market and the state, espoused by scholars such as Hayek. Ostrom maintains that neither the state nor the market is uniformly successful in enabling individuals to sustain long-term, productive use of natural resource systems. ${ }^{29}$ The solution, according to Ostrom, lies in the requirement for greater institutional diversity. She suggests that the 'Tragedy of the Commons' could also be avoided if the parties concerned were to make a binding contract under which they commit themselves to a cooperative strategy mutually agreed between the actors concerned. ${ }^{30}$ Ostrom provides the empirical example of fisherman on a lake at Alanya, Turkey, as evidence of such a cooperative strategy in

\footnotetext{
${ }^{28}$ [1994] 3 IR 1

${ }^{29}$ E Ostrom, Governing the Commons, The Evolution of Institutions for Collective Action (Cambridge University Press, Cambridge 1990) 1

${ }^{30}$ Ostrom, Governing the Commons, 15
} 
action. At Alanya, the local fishermen entered into an agreement regarding the regulation of fishing rights on a local lake, which is a finite resource. Ostrom observed that compliance with the system is regulated by the fishermen themselves and that each fisherman's rights, where infringed, are supported by everyone else in the system. ${ }^{31}$

For sure, Ostrom's solution of a cooperative strategy to overcome disputes regarding property rights cannot be truly effective in the context of a deeply embedded regime which often ranks highly the right of land owners to exclude others from their property, as exists in Ireland. The hypothesis is also rendered less effective as, by definition, the entry of a private developer, through compulsory acquisition, introduces a new actor who is not privy to the local cooperative strategy. However, the underlying importance of institutional diversity, as a means of encouraging a greater balance of governance, is particularly relevant to the compulsory acquisitions which have been considered in this essay.

The irony of Kelo and Clinton is that the judgments in each go some way to satisfying both those scholars, outlined above, who uphold the dichotomy between market and state and also Ostrom. The very fact that the power of compulsory acquisition in Clinton was delegated to a local authority, rather than exercised by the centralised state, demonstrates that the Irish legal order does recognise the benefits of decentralising authority to local experts who are better placed to make such decisions. However, the exercise of these powers by local, rather than central, government also opens up space for the cooperative institutional diversity which is espoused by Ostrom. The strengthening of citizen participation in local governance would go a long way to regulating the use of the eminent domain. This would help to ensure that compulsory acquisitions only take place where they are of defined benefit to the overall community, irrespective of whether the initial beneficiary of such development is a private actor. If such participation were to become embedded, it is also likely that local government decisions to compulsorily acquire private property for regeneration would not precipitate the public outcry, or legislative reactionism, which followed Kelo in America, as decisions would have greater democratic legitimacy.

\section{The Role Of LAW AS Cognitively Open}

However, embedded democratic local governance structures which seek to ensure the best solution for the entire local polity cannot solve all disputes which arise from compulsory acquisition. "Hold-outs" and "hold-ins" are likely to continue to act in a self interested fashion irrespective of the whether a development scheme is supported by a majority in their community. Therefore, it will never be possible to entirely oust the role of law, as a final port of call, in balancing the rights of those parties who are in dispute.

In a heterogeneous society, the nature of property is constantly evolving. In 2005, National Geographic highlighted that 20 percent of the human genome had been

${ }^{31}$ Ibid., 20 
patented. ${ }^{32}$ The holding of this form of intellectual property could not have been contemplated a generation previous. It is no longer possible for the courts, in balancing the private rights of individuals and the state, within a constitutional framework, to simply rely on the rule of law or to defer entirely to a welfarist state.

Nancy Fraser has also suggested that the traditional dichotomy of market versus state is no longer relevant. She has stated that neither "reductive economism" nor "romanticised society" can singularly provide a governance regime to meet the needs of a complex society. Instead she suggests that a third variable must be introduced into the equation, namely the search for emancipation. This third axis serves to cross-cut the conflict between marketisation and social protection; it does not inherently sway towards either extreme. According to Fraser, the introduction of a variable which seeks emancipation serves to "overcome forms of subjection rooted in society". ${ }^{33}$

It is clear that where local or private bargaining breaks down the role of the law, and by extension of the courts, will become of central importance. In introducing a place for emancipation, which the Irish courts do by way of the proportionality doctrine outlined above, the Irish legal system seeks to act as the facilitator of an endless political discourse, often dominated by extreme interests. It was demonstrated, by the fact that the Irish Supreme Court has seldom struck down a law which seeks to acquire property compulsorily, that the courts will in most cases defer to "majority rule". However, as per the Supreme Court in Tuohy, where majority rule is "so contrary to reason and fairness as to constitute an unjust attack on some individual's constitutional rights", the role of the State in regulating private property will be limited by the courts.

\section{CONCLUSION}

It is evident from the foregoing discussion that property rights are not sacrosanct under Irish law. In most instances where compulsory acquisition by the State, or an organ thereof, has been contested before the courts, a deferential attitude towards the authority of the legislature is apparent. There has been a concern expressed that at times of economic crisis the state may transgress beyond the acceptable limits of such intervention; in a manner which infringes the rights of some citizens in favour of private gain for others, in order to stimulate economic growth. However, these concerns are misplaced. The very fact that the initial beneficiary of a development is a private actor is not sufficient to conclude that no public benefit will accrue from a compulsory acquisition, no more than the very fact that a private actor is not involved is sufficient to conclude that a public benefit will result.

\footnotetext{
${ }^{32}$ S Lovgren, 'One-Fifth of Human Genes Have been Patented, Study Reveals'

< http://news.nationalgeographic.com/news/2005/10/1013_051013_gene_patent.html> Accessed 6 May 2010

33 N Fraser, 'Marketization, Social Protection, Emancipation: Towards a Neo-Polanyian Conception of Capitalist Crisis' Giambattista Vico Lecture (York University, Toronto, 19 November 2009)
} 
Therefore, the concern of the law should not be whether to provide absolute protection to private land owners from all forms of acquisition which ostensibly benefit private actors to a greater degree than the public. Rather, the aim of the law should be to regulate the market and the state in a manner which balances those competing variables alongside a concern for justice - or emancipation - which may not inherently favour either state or market. Through the doctrine of proportionality, as outlined in Tuohy, this is the approach of the Irish courts to disputes regarding compulsory acquisition, irrespective of whether the acquisition is purely public in nature, or includes a private dimension.

The above does not imply that the role of private or cooperative bargaining is redundant; in many cases it is preferable. The notion of institutional diversity, as espoused by Elinor Ostrom, can indeed serve as a model for providing greater legitimacy to decisions by local authorities to compulsorily acquire land in their locality. The strengthening of citizen participation in such bodies, alongside experts, would make less likely the reactionary outcome of the US Supreme Court's decision in Kelo. However, it must be recognised that such bargaining has natural limitations, particularly where one party acts as a "hold in" in an area earmarked for necessary regeneration.

It is likely that a case with facts synonymous to Kelo will come before the Irish Supreme Court at some point in the future. Given the past record of the court, provided an acquisition similar to that in Kelo is not so repugnant as to constitute an unjust attack on one's constitutional rights, it seems likely that the Supreme Court will follow the path their American counterparts. Given the fact that the Supreme Court's general deference to the legislature in these matters has not aroused any great political debate in the past, it is unlikely that a decision synonymous to Kelo would spark an outcry similar to that which occurred in America. However, the adoption of a model of increasing institutional diversity, as outlined above, is likely to give greater democratic legitimacy to such acquisitions. This would make even less likely a populist movement aimed at imposing undue restrictions on the state's ability to exercise its power of compulsory acquisition. Such institutional diversity should be particularly encouraged during periods of economic crisis, when disputes of the nature outlined in this essay are increasingly likely to occur. 


\section{BIBLIOGRAPHY}

$\underline{\text { General }}$

R Coase, 'The Problem of Social Cost' (1960) 3 Journal of Law and Economics 1-44

S Crow, 'Compulsory Purchase for Economic Development: An International Perspective' (2007) J.P.L 1102-1115

RC Ellickson, Order without Law: how neighbors settle disputes (Harvard University Press, London 1991)

G Hardin, 'The Tragedy of the Commons' (1968) 162 Science 1243-1248

FA Hayek, 'The Use of Knowledge in Society' (1945) 35 The American Economic Review 519-530

GW Hogan and GF Whyte, JM Kelly: The Irish Constitution (4 ${ }^{\text {th }}$ edn Tottel, Dublin 2003)

J Nadler and SS Diamond, 'Eminent Domain and the Psychology of Property Rights:

Proposed Use, Subjective Attachment, and Take Identity' Northwestern Public Law

Research Paper No. 08-24. Available at http://ssrn.com/abstract=1162789

E Ostrom, Governing the Commons, The Evolution of Institutions for Collective Action (Cambridge University Press, Cambridge 1990)

E Rutkow, 'Kelo v City of New London' (2006) 30 Harv.Envtl.L.Rev. 261-279

CM Tiebout, 'A Pure Theory of Local Expenditures' (1956) 64 Journal of Political Economy 416-424

\section{Other Materials}

Castle Coalition, 'Legislative Center'

<http://www.castlecoalition.org/index.php?option=com_content\&task=view\&id=34\&lte mid=119> Accessed 3 May 2010

Editorial, 'The Limits of Property Rights', New York Times (New York 24 June 2005)

Editorial, 'Pfizer and Kelo's Ghost Town' Wall Street Journal (New York 11 November 2009)

N Fraser, 'Marketization, Social Protection, Emancipation: Towards a Neo-Polanyian Conception of Capitalist Crisis' Giambattista Vico Lecture (York University, Toronto, 19 November 2009)

S Lovgren, 'One-Fifth of Human Genes Have been Patented, Study Reveals'

< http://news.nationalgeographic.com/news/2005/10/1013_051013_gene_patent.html> Accessed 6 May 2010 
P McGeehan, 'Pfizer to Leave City That Won Land-Use Suit' New York Times (New York 13 November 2009)

F O'Dowd, 'Hanger 6 at Dublin Airport: Discussion' (Joint Committee on Transport, 24 February 2010)

Report of the Constitutional Review Group (Pn 2632, 1996)

Ryanair, 'Irish Government Inaction Cost 500 Engineering Jobs Which will now be lost to Europe'<http://www.ryanair.com/en/news/irish-govt-inaction-costs-500-engineeringjobs> Accessed 4 May 2010

R Walsh, 'Compulsory Acquisition for Private Redevelopment - Lessons from the U.S.' $<$ http://humanrights.ie/2010/03/06/guest-contribution-walsh-on-compulsoryacquisition-for-private-development/> Accessed 17 March 2010

Legislation

Basic Law for the Federal Republic of Germany

Bunreacht na hÉireann

Declaration of the Rights of Man and of the Citizen, 1789

European Convention on Human Rights

Planning and Compulsory Purchase Act, 2004

United States Constitution

Case Law

Clinton v An Bord Pleanála [2007] IESC 19

Hawaii Housing Authority v Midkiff, 467 U.S. 229 (1984)

larnród Éireann v Ireland [1996] 3 IR 321

Kelo v City of new London 545 U.S. 469 (2005)

Lochner v New York 198 U.S. 45 (1905)

Sturges v Bridgman [1879] LR 11 Ch D 852

Tuohy v Courtney [1994] 3 IR 1 